\title{
Phytopathology
}

\section{Verticillium Systematics and Evolution: How Confusion Impedes Verticillium Wilt Management and How to Resolve It}

\author{
Patrik Inderbitzin and Krishna V. Subbarao
}

Department of Plant Pathology, University of California, Davis.

Accepted for publication 10 February 2014.

\begin{abstract}
Inderbitzin, P., and Subbarao, K. V. 2014. Verticillium systematics and evolution: How confusion impedes Verticillium wilt management and how to resolve it. Phytopathology 104:564-574.

Verticillium wilts are important vascular wilt diseases that affect many crops and ornamentals in different regions of the world. Verticillium wilts are caused by members of the ascomycete genus Verticillium, a small group of 10 species that are related to the agents of anthracnose caused by Colletotrichum species. Verticillium has a long and complicated taxonomic history with controversies about species boundaries and long overlooked cryptic species, which confused and limited our knowledge of the biology of individual species. We first review the taxonomic history of Verticillium, provide an update and explanation of the current system of classification and compile host range and geographic distribution data for individual species from internal transcribed spacer (ITS) GenBank records. Using Verticillium as an example, we show that species names are a poor vehicle for archiving and retrieving information, and that species identifications should always be backed up by DNA sequence data and DNA extracts that are made publicly available. If such a system were made a prerequisite for publication, all species identifications could be evaluated retroactively, and our knowledge of the biology of individual species would be immune from taxonomic changes, controversy and misidentification. Adoption of this system would improve quarantine practices and the management of diseases caused by various plant pathogens.
\end{abstract}

Verticillium is a small genus of ascomycete plant pathogens that causes Verticillium wilt diseases, a type of vascular wilt. Verticillium wilts are among the most devastating fungal diseases worldwide and affect hundreds of different plant species including high value agricultural crops (62). Verticillium wilt is most important in temperate regions, occurs less frequently in the subtropics, and is rare in tropical regions of the world $(32,34$ $36,41,62)$. Economic losses of $50 \%$ or higher commonly occur on high value crops, including cotton (22), lettuce $(4,80)$, olive (49), and potato (71). In strawberry without soil fumigation, losses of up to $75 \%$ have been recorded (91). Many more important crops and ornamentals (62) are affected, but precise loss estimates are not readily available.

Verticillium species are soilborne and are able to survive in the soil by means of melanized resting structures without a host for at least 14 years (90). Resting structures are microsclerotia, chlamydospores, or resting mycelia, depending on the species (41).

\section{Corresponding author: K. V. Subbarao; E-mail address: kvsubbarao@ucdavis.edu}

*The $\boldsymbol{e}$-Xtra logo stands for "electronic extra" and indicates that the online version contains six supplemental data files.

http://dx.doi.org/10.1094/PHYTO-11-13-0315-IA

(c) 2014 The American Phytopathological Society
Host infections are initiated upon germination of the resting structures and are followed by penetration into roots, slow progression through the vasculature, and entry into the shoots (21). Distinct external symptoms including wilting and tissue necrosis typically appear only near the end of the disease cycle and often coincide with host maturity (48). Verticillium management therefore relies on the elimination of resting structures. Soil fumigation is most effective, but methyl bromide, the most widely used soil fumigant, has been phased out (20), which has compounded the problem caused by Verticillium in agriculture. The critical use exemptions that have prolonged the use of methyl bromide in strawberry production in California will cease by 2015 unless renewed.

In addition to being plant pathogens, Verticillium species are also known to colonize plants without triggering symptoms $(56,64)$, which is in agreement with an endophytic life style but few details are known. Human or animal infections have not been reported for Verticillium.

There are 10 Verticillium species (41), of which $V$. dahliae has the greatest economic impact and infects over 200 host species worldwide (62). The other species have narrower host ranges and more restricted global distributions $(35,41)$, but $V$. albo-atrum (63), V. alfalfae (37), V. longisporum $(5,19), \quad V$. nonalfalfae $(18,65), V$. tricorpus (63), and V. zaregamsianum (83) are known to cause significant losses. Verticillium nubilum is a minor patho- 
gen and only causes disease on tomato and potato in pathogenicity tests (46). The agricultural importance of $V$. isaacii and $V$. klebahnii (41) is unknown, but they were isolated from lettuce and artichoke $(41,64)$.

\section{THE REDEFINED GENUS VERTICILLIUM SENSU STRICTO}

Verticillium is among the older genera of filamentous fungi and was established in 1817 by Nees von Esenbeck (59) for $V$. tenerum from a stem of hollyhock (Alcea rosea L.) in Germany (Fig. 1) $(3,73,84)$. The first plant-pathogenic Verticillium species, V. albo-atrum, was described in 1879 from diseased potato plants in Germany (67). Many more species were added over the years, and Verticillium grew into an ecologically diverse genus of around 190 species (97), which in addition to saprobes and plant pathogens, also included pathogens of animals and fungi. Because of this heterogeneity, Verticillium was first divided into different sections $(24,25)$, and later DNA sequence data were used to identify distantly related species that were transferred to other genera (26,94-96), a process that is still underway (42). To avoid changing names of major Verticillium plant pathogens, the genus Verticillium was redefined with $V$. dahliae as the type species, a nomenclatural maneuver known as conservation (27). Verticillium species that belong to the same clade as $V$. dahliae are now referred to as Verticillium sensu stricto (s.s.), which excludes distantly related, residual Verticillium species awaiting transfer to other genera. Of the major Verticillium plant pathogens, only Musicillium theobromae formerly known as V. theobromae, is not part of Verticillium s.s. (98).

Verticillium s.s. is a member of the family Plectosphaerellaceae (98) in the subclass Hypocreomycetidae of the class Sordario- mycetes, which is in the phylum Ascomycota (99). In addition to M. theobromae, the family Plectosphaerellaceae also harbor the generally minor plant pathogens Gibellulopsis nigrescens $(33,98)$, Lectera colletotrichoides (13), and Plectosphaerella cucumerina (66). Related to the family Plectosphaerellaceae is the family Glomerellaceae (99), which contains Colletotrichum, the causal agents of anthracnose diseases (54). In this review, the name Verticillium is used in place of Verticillium s.s. unless indicated otherwise.

\section{A HISTORY OF TAXONOMIC CONTROVERSIES AND SHIFTING SPECIES BOUNDARIES IN VERTICILLIUM}

The history of Verticillium is rife with taxonomic controversies and shifting species boundaries that have profoundly confused our knowledge of the biology of individual species. Verticillium dahliae and $V$. albo-atrum, which historically are the two most important species, have been most affected. Due to taxonomic disagreements, $V$. dahliae was first confounded with $V$. albo-atrum and then with $V$. longisporum, and the two cryptic species $V$. alfalfae and $V$. nonalfalfae were recently described from $V$. albo-atrum. Thus, the meanings of the names $V$. albo-atrum and $V$. dahliae have changed over time and have depended on when and by whom they were used.

The longest-lasting controversy was about whether $V$. dahliae that was described in 1913 (51) should be a separate species from the earlier described V. albo-atrum (67). Much of the early literature does not raise any doubts about the status of $V$. dahliae, which was published with careful illustrations, descriptions, and comparisons to $V$. albo-atrum that differed most prominently in the morphology and the development of resting structures (51). These results were independently confirmed and illustrated from
FIGURE 1

Original illustration of Verticillium tenerum from 1817 by Nees von Esenbeck in 'Das System der Pilze und Schwämme', Plate 4, Illustration 55. Downloaded from Universitätsbibliothek Heidelberg at http://digi.ub.uniheidelberg.de/diglit/neesvonesenbeck1817/0473.

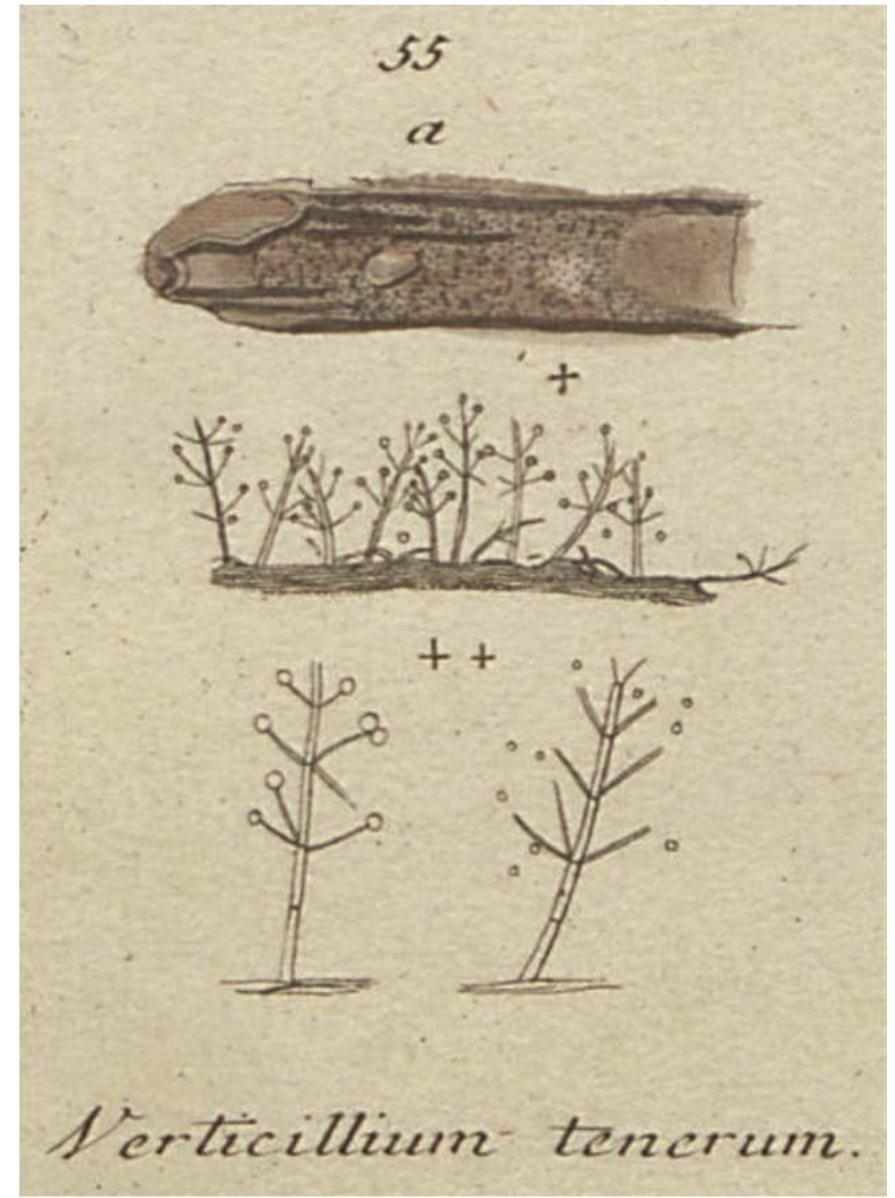


Australia (55), Europe (88), and North America (7), and physiological differences between the two species were also detected. But Wollenweber (93) and Rudolph (72) disagreed, and their works were very influential (89), despite the fact that Wollenweber (93) only supported his arguments by illustrations of $V$. dahliae, and Rudolph (72) did not include any new illustrations at all. Over the years, there were further dueling publications for and against $V$. dahliae with proponents discovering additional physiological differences between the two species $(45,69)$, and opponents emphasizing that resting structure morphology was not suitable for species separation $(87,92)$. During this time, opinions about the status of $V$. dahliae were approximately evenly divided (69). The tide finally turned in favor of $V$. dahliae in the $1970 \mathrm{~s}$ (89), as is illustrated by the ratios of $V$. dahliae to $V$. albo-atrum counts on Google Scholar (www.scholar.google.com) over 10year periods from 1914, the year after publication of $V$. dahliae, to 2013 (Fig. 2; Supplemental data 1). Despite $V$. dahliae being much more widespread and more commonly isolated $(86,93), V$. albo-atrum counts on Google Scholar outnumbered V. dahliae counts by generally more than two to one until the beginning of the 1970s (Fig. 2). For the first time, V. dahliae counts were higher than the ones for V. albo-atrum between 1974 to 1983, and between 2004 to 2013 V. dahliae counts outnumbered V. alboatrum counts by more than four to one. The uptick of $V$. dahliae over V. albo-atrum counts in the beginning of the 1970s correlates with comprehensive reviews in favor of $V$. dahliae published in the 1960s $(47,77)$. The two papers were relatively highly cited throughout the 1970s and up to this day (data not shown). The fact that none of the $V$. dahliae internal transcribed spacer (ITS) sequences in GenBank were mislabeled as V. albo-atrum (Fig. 3) shows that the controversy has been resolved.

Another taxonomic controversy affecting $V$. dahliae concerned the recognition of $V$. longisporum as a separate species instead of a variety of $V$. dahliae $(50,78)$. The debate was short-lived $(6,15)$, and the name $V$. longisporum is now widely accepted. There were 93 hits on Google Scholar for V. longisporum in 2012, as opposed to seven for $V$. dahliae var. longisporum, and none of the latter questioned the status of $V$. longisporum (data not shown).

\section{PHYLOGENETIC SPECIES IN VERTICILLIUM ARE LINKED TO HERBARIUM TYPE SPECIMENS}

The names of fungal species are permanently linked to type specimens through the rules of the International Code of Nomen-
FIGURE 2

Ratios of Verticillium dahliae to Verticillium albo-atrum counts on Google Scholar in 10-year windows from 1914 to 2013.
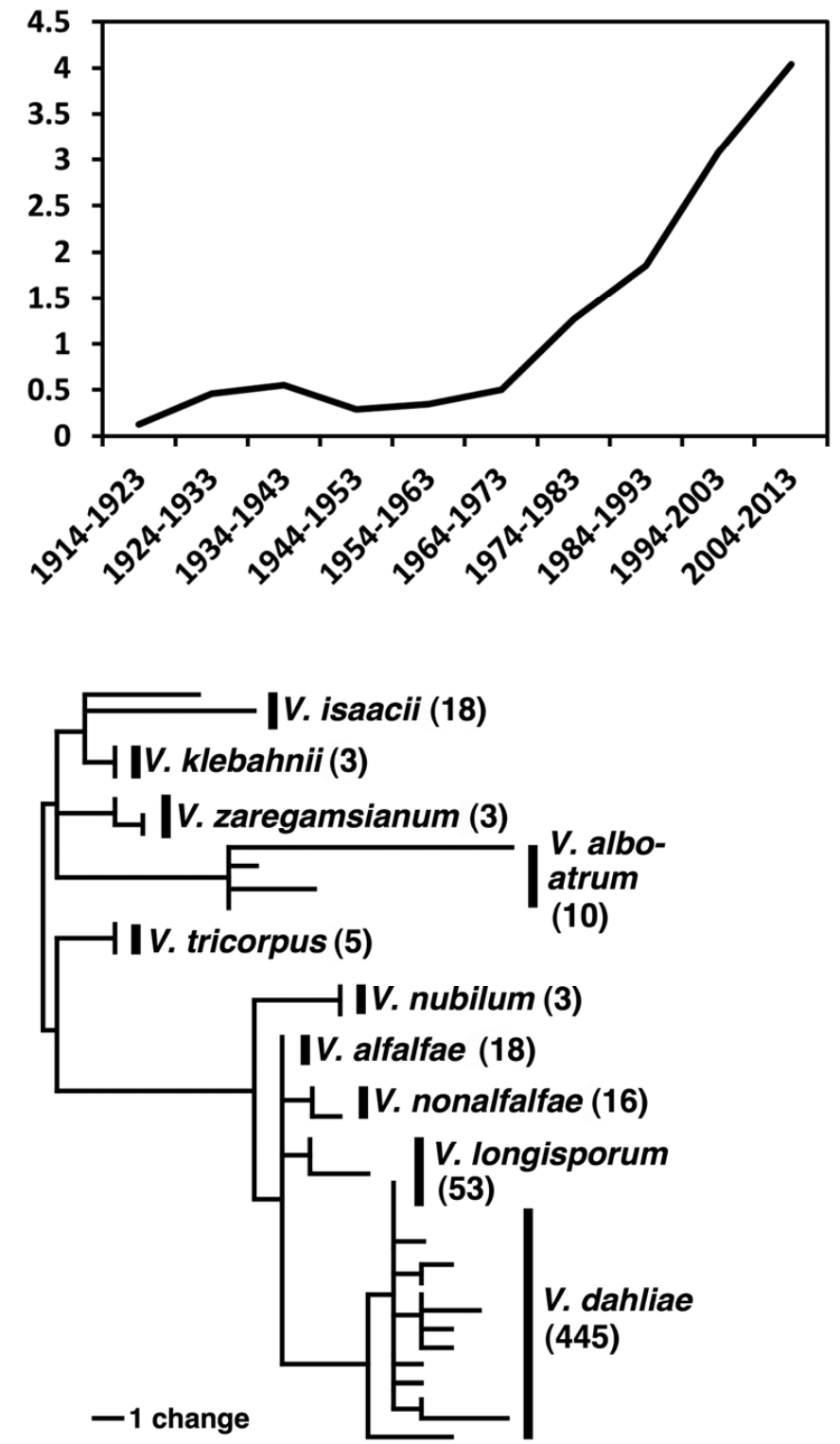

-1 change
FIGURE 3

Cartoon of a phylogenetic tree with 574 Verticillium internal transcribed spacer (ITS) sequences from GenBank illustrating that all ITS sequences fall into 1 of 10 Verticillium species, with the exception of eight isolates of $V$. longisporum lineage A1/D3 that have $V$. dahliae ITS regions. Species are delimited by vertical bars and the numbers of ITS sequences in each species are given in parentheses following species names. Branch lengths are

to scale and tree is unrooted. Supplemental data files provide details of ITS sequence retrieval, alignment, tree generation, DNA sequences, phylogenetic topology, and the alignment. 
clature (ICN) for algae, fungi, and plants (57), but similar regulations for the definition of species themselves do not exist. The phylogenetic species concept is probably the most widely used framework for the definition of fungal species today. Recognition of phylogenetic species requires an understanding of evolutionary relationships that are described by a phylogenetic tree, and species status is assigned to individual groups in the tree $(31,81)$. Since the phylogenetic groups are nested, and each group is part of a larger group, different criteria can be used to decide how many nested groups should constitute a species. The recognition criteria include phenotypic (31), genotypic or ecological characters, or genealogical concordance (81). Names are assigned to species-level phylogenetic groups by the type specimens that cluster within them. This is an intellectually satisfying approach since the criteria used to recognize species are known and the species are named in accordance with the nomenclatural rules of the ICN. Another advantage of the phylogenetic species concept is that all members of a species are more closely related to one another. Thus, members of a species are overall more similar to one another than to other species, both in terms of host range, fungicide resistance, reproduction system, and virulence, and other characters of importance to plant pathology. Substitutions at the DNA level are also more likely to be shared among members of the same species, which facilitates the design of speciesspecific diagnostic polymerase chain reaction (PCR) assays.

A recent revision of Verticillium recognized phylogenetic species that were named by integration of herbarium type specimens as described above (41). This became necessary because earlier studies showed that $V$. albo-atrum consisted of not one but two groups that were distantly related $(6,58,68)$, the phylogenetic position of the hybrid $V$. longisporum was uncertain $(14,15,50)$, and DNA sequence data and type specimens themselves were missing for some of the Verticillium species. Those concerns were addressed in studies of 257 isolates, which led to the recognition of five new species $(41,43)$. The original description of $V$. alboatrum (67) revealed that the name $V$. albo-atrum should be restricted to the lineage that is closely related to $V$. tricorpus, whereas the two groups closer to $V$. dahliae were named $V$. alfalfae and $V$. nonalfalfae, respectively. Verticillium alfalfae and $V$. nonalfalfae are each other's closest relatives and were delimited by differences in host preference, mating types (41), and vegetative compatibility groups (17). Similarly, V. tricorpus and the three cryptic species separated from it are closest relatives. These include $V$. zaregamsianum that is morphologically distinct and forms predominantly microsclerotia and yellow-pigmented hyphae. And V. isaacii and V. klebahnii, which share the same morphology as $V$. tricorpus, but collectively are about as diverse as the group formed by $V$. alfalfae, $V$. dahliae, and $V$. nonalfalfae at the loci examined. Also, there is evidence for differences in pathogenicity between V. isaacii, V. klebahnii, and V. tricorpus $(41,64,85)$. As opposed to other important plant pathogens including Fusarium (60), species complexes have not been described in Verticillium. In comparison to Fusarium species complexes, each Verticillium species corresponds to a single phylogenetic group with relatively little variation and generally few well-supported subspecific groupings $(41,43)$.

The 10 Verticillium species are apparently sufficient to accommodate the currently known diversity, because phylogenetic analyses of the Verticillium ITS sequences from GenBank demonstrated that all sequences grouped with 1 of the 10 species (Fig. 3; Supplemental data 2, 3, 4, and 5). The exceptions were $V$. dahliae and the diploid hybrid $V$. longisporum as explained below.

\section{THE DIPLOID HYBRID V. LONGISPORUM EVOLVED MULTIPLE TIMES}

V. longisporum is a diploid hybrid and is an exception to the rule that a species should correspond to just one phylogenetic group. This is because the parents of $V$. longisporum represent four different lineages from three different species, which hybridized at least three different times, resulting in the three V. longisporum lineages that are known today (43) (Fig. 4). The parental species include $V$. dahliae, and two unknown species that have never been found and were provisionally named Species A1 and Species D1. Except for the ribosomal repeat region, V. longisporum isolates comprise two alleles for all genes examined $(43,82)$. The naming of hybrids that evolved multiple times has not been settled in mycology (10). In plants, Brochmann et al. (11) used morphological differences as criteria to name different lineages of a hybrid.

The $V$. longisporum hybrid origin presents difficulties for the identification by PCR assay or DNA sequence data. The V. longisporum ITS region was inherited from Species A1 for two of the $V$. longisporum lineages, lineages $\mathrm{A} 1 / \mathrm{D} 1$ and $\mathrm{A} 1 / \mathrm{D} 2$, or from $V$. dahliae for the V. longisporum lineage A1/D3 (Fig. 4). Thus, PCR tests and DNA sequence comparisons based on the ITS region will falsely identify $V$. longisporum lineage A1/D3 as $V$. dahliae. Multiplex PCR assays are now available for the differentiation of $V$. dahliae from all lineages of V. longisporum (44).

\section{PHYLOGENETIC RELATIONSHIPS IN VERTICILLIUM CORRELATE WITH YELLOW HYPHAL PIGMENTATION}

Phylogenetic studies showed that Verticillium consisted of two major lineages $(6,98)$ that correlate with yellow hyphal pigmentation (41). All species of the clade Flavexudans produce yellow

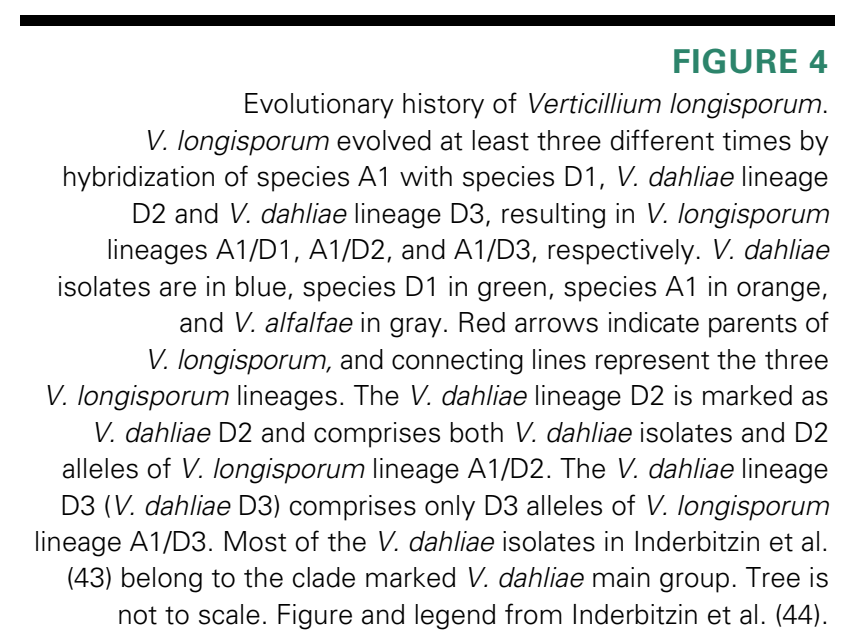

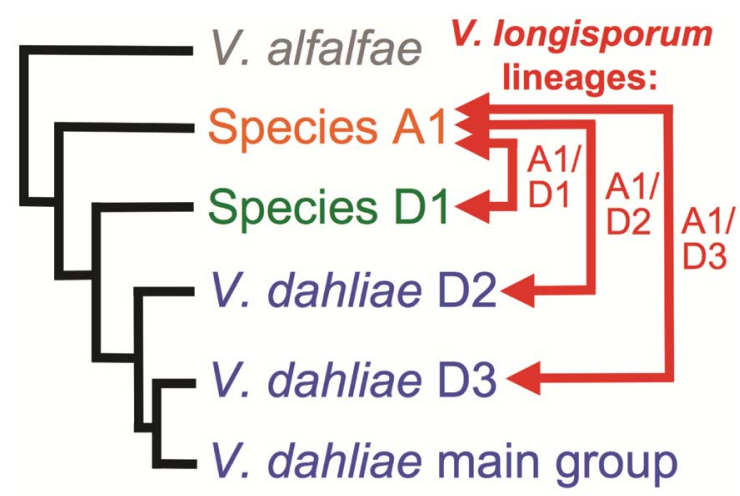


hyphal pigments, including V. albo-atrum, V. isaacii, V. klebahnii, $V$. tricorpus, and $V$. zaregamsianum, whereas lineage Flavnonexudans lacks yellow pigmentation and consists of species $V$. alfalfae, $V$. dahliae, $V$. longisporum, $V$. nonalfalfae, and V. nubilum. Plant pathogens are present in both lineages. The relationships of Verticillium species are generally well resolved, but further studies are needed to confirm the grouping of V. nubilum with the clade Flavnonexudans, and Species $\mathrm{A} 1$, an unnamed $V$. longisporum ancestor, with $V$. dahliae and Species D1, another $V$. longisporum ancestor that has also not been recovered thus far $(41,43)$.

\section{HOST RANGES AND GEOGRAPHIC DISTRIBUTIONS OF VERTICILLIUM SPECIES}

Verticillium species are able to infect a large number of plant species. Verticillium dahliae alone has been recorded from several hundred hosts (62). How many of these reports are true is difficult to verify because of taxonomic confusion of $V$. dahliae with $V$. albo-atrum and $V$. longisporum at different points in history. A compilation of host information from 574 Verticillium ITS GenBank records that were assigned to species using phylogenetic analyses (Fig. 3), and the host information in Inderbitzin et al. $(41,43)$, confirmed that $V$. dahliae had the most hosts among Verticillium species with 74, which were from 14 orders of seed plants including Asterales, Brassicales, Caryophyllales, Cucurbitales, Fabales, Lamiales, Magnoliales, Malpighiales, Malvales, Ranunculales, Rosales, Sapindales, Solanales, and Vitales (Table $1)$. Most of the orders are part of the eudicots where they represent many of the major lineages, whereas Magnoliales belongs to the magnoliids (79). Among seed plants, the most prominent groups that according to this survey are not hosts of $V$. dahliae are gymnosperms and monocots. However, there are reports of $V$. dahliae from gymnosperm and monocot hosts, and even from horsetail (Equisetum arvense) (62). Thus, V. dahliae may be infecting most lineages of seed plants and potentially other plants including pteridophytes, which likely constitutes one of the broadest host ranges of any fungal plant pathogen.

Host counts were lower for the other Verticillium species, ranging from 1 to 10 hosts. Verticillium longisporum hosts are mainly in the family Brassicaceae, with sugar beet being the only exception. The single host of $V$. alfalfae was alfalfa, the one for $V$. nubilum was potato, and both hosts of V. klebahnii were in the family Asteraceae. The remaining species had a broader host range (Table 1).

Most records of Verticillium species are from agricultural crops or plants associated with agriculture or from ornamentals and little is known about host ranges in natural ecosystems. This is particularly striking for $V$. dahliae where none of the hosts in Table 1 could be confirmed to be collected from a natural habitat. Two strains of V. albo-atrum were isolated from Petasites hybridus in a nature reserve in the Netherlands, and from Urtica dioica in a mountainous region of Scotland (W. Gams, personal communication). One $V$. nonalfalfae strain was from Ailanthus altissima in the Tuscarora State Forest in south-central Pennsylvania (74).

One problem with using the ITS as a species marker in Verticillium is that $V$. longisporum lineage A1/D3 has a $V$. dahliae ITS region, and the two species can thus be confused. This is illustrated by the fact that in Figure 3 eight ITS sequences labeled $V$. longisporum clustered with $V$. dahliae. The potential for confusion between $V$. dahliae and $V$. longisporum may be greatest in the Brassicaceae that are the main hosts for $V$. longisporum. To evaluate whether some of the $V$. dahliae reports on Brassicaceae hosts may instead be $V$. longisporum, we consulted additional data from the literature including multigene phylogenies, conidial DNA content, and VCGs, which showed that all eight $V$. dahliae Brassicaceae hosts for which such data was available, could be confirmed as $V$. dahliae hosts (Table 1). Outside of the Brassicaceae, it appears that due to the narrow host range of $V$. longisporum, confusion with $V$. dahliae based on ITS may be unlikely. However, when working with $V$. dahliae, other data in addition to the ITS region should be recorded in support of strain identification.

Mirroring the host range data, $V$. dahliae was most widely distributed among Verticillium species and occurred on all inhabited continents. Verticillium klebahnii and V. nubilum were the only two species that were confined to a single country, the United States and the United Kingdom, respectively (Table 1).

\section{IDENTIFICATION OF VERTICILLIUM SPECIES}

Our knowledge of the biology of Verticillium species hinges on correct, consistent, and verifiable identification of the strains collected from the environment and used in experiments. Whereas the future of identification may lay in DNA barcoding (53), Verticillium species are currently most often diagnosed by morphological examination using light microscopy or by sequencing of the ITS region followed by a blast search (1) at GenBank. Morphological identification is appropriate under certain situations, but the characters used for identification, including resting structures and yellow hyphal pigmentation, are unstable and may disappear in laboratory cultures, and some Verticillium species lack distinguishing morphological characteristics (41). The ITS region is the official barcoding region for fungi (75), and is also most widely used for DNA-based identification in Verticillium. Except for the hybrid V. longisporum, all Verticillium type specimens have unique ITS sequences (41). However, the ITS is similar for some groups of Verticillium species and may vary within species, which complicates species identification. This is illustrated by a nucleotide blast query (blastn) at GenBank with a $V$. nonalfalfae ITS sequence (GenBank Accession $\mathrm{AB} 458830$ ) that resulted in four equally close matches, three with V. nonalfalfae sequences (HE972032, HE972033, and FJ424082) and one with a V. longisporum sequence (GQ495792). A secondary barcode that is more variable than the ITS region (75) may be useful in Verticillium. A candidate is the elongation factor 1-alpha $(E F)$, the most variable locus for Verticillium in Inderbitzin et al. (41).

Phylogenetic analyses are another way to compare query sequences with a reference data set for species identification, and appear to be better suited than blast for the Verticillium ITS region. In the ITS tree in Figure 3, all sequences, except the ones of the hybrid $V$. longisporum, fall into distinct groups, and each group contains a different type specimen. This suggests that all sequences in the tree represent one of the established Verticillium species. However, phylogenetic analyses based on multiple loci (81) are much more accurate for species identification, they provide more power for the detection of new species than single locus phylogenetic analyses, and are also able to detect hybrids. A reference data set for phylogenetic analyses is available at TreeBase (41) under Study 11756, strains representing type specimens are marked in bold in Figure 1 of Inderbitzin et al. (41). Other methods of DNA sequence comparison for species identification are available (16) and may become more popular in the future.

An issue that hampers DNA-based species identification is the high proportion of misidentified sequences in GenBank. For Verticillium species, we found that between 5 to $81 \%$ of GenBank ITS sequences represented incorrectly identified species (Fig. 5). Most commonly mislabeled were $V$. tricorpus ITS sequences, whereas only $5 \%$ of the $V$. dahliae ITS sequences were misidentified. Since the $V$. longisporum lineage A1/D3 ITS region is indistinguishable from the one of $V$. dahliae, the proportion of mislabeled $V$. dahliae ITS sequences may be higher. Misidentified 
TABLE 1

Substrates and geographic distribution of Verticillium species based on 821 GenBank ITS records ${ }^{\mathrm{a}}$

Species

Substrates

V. albo-atrum Reinke \& Berthold Pestilence wort (Petasites hybridus), Potato (Solanum tuberosum), Soil, Stinging nettle (Urtica dioica)

V. alfalfae Inderb. et al. Alfalfa (Medicago sativa)

V. dahliaeb Kleb.

African eggplant (Solanum aethiopicum), Alectryon (Alectryon sp.), Almond (Prunus dulcis), American black nightshade (Solanum nigrum), Anaheim pepper (Capsicum annuum), Apricot (Prunus armeniaca), Artichoke (Cynara scolymus), Aztec marigold (Tagetes erecta), Bell pepper (Capsicum annuum), Black raspberry (Rubus sp.), Black-eyed Susan (Rudbeckia hirta), Brassica oleracea var. capitatac ${ }^{c}$ Brassica oleracea var. italica ${ }^{c}$, Broccoli (Brassica oleracea var. botrytis) ${ }^{c}$, Cabbage (Brassica oleracea) ${ }^{c}$, Celandine (Chelidonium majus), Chamomile (Matricaria chamomilla), Chicory (Cichorium intybus), Chili pepper (Capsicum annuum), Chinese cabbage (Brassica oleracea), Coleus (Coleus verschaffeltii), Coneflower (Echinacea purpurea), Cosmos (Cosmos bipinnatus), Cota palaestina, Cotton (Gossypium hirsutum), Cyprusvetch (Lathyrus ochrus), Eggplant (Solanum melongena), European smoketree (Cotinus coggygria), European yellow lupine (Lupinus luteus), Figmarigold (Lampranthus spp.), Flax (Linum usitatissimum), French marigold (Tagetes patula), Grapevine (Vitis vinifera), Green ash (Fraxinus pennsylvanica), Horseradish (Armoracia rusticana)c, Icelandic poppy (Papaver nudicaule), Italian cockleburr (Xanthium italicum), Jalapeno (Capsicum annuum), Japanese maple (Acer palmatum), Lactuca sativa var. Iongifolia, Lambsquarters (Chenopodium album), Lenspod whitetop (Cardaria draba)', Lettuce (Lactuca sativa), Lupine (Lupinus polyphyllus), Nestegis sp., New Zealand spinach (Tetragonia tetragonioides), Norway maple (Acer platanoides), Oilseed rape (Brassica napus sp. oleifera)c, Okra (Abelmoschus esculentus), Old-man-in-the-Spring (Senecio vulgaris), Olive (Olea europaea), Opium poppy (Papaver somniferum), Orange coneflower (Rudbeckia fulgida), Paprika (Capsicum annuum), Peach (Prunus persica), Peanut (Arachis hypogaea), Peppermint (Mentha x piperita), Pistachio (Pistacia vera), Potato (Solanum tuberosum), Pumpkin (Cucurbita pepo), Purple coneflower (Echinacea purpurea), Radish (Raphanus raphanistrum), Rose (Rosa sp.), Scentless false mayweed (Tripleurospermum perforatum), Skullcap (Scutellaria lateriflora), Soil, Spinach (Spinacia oleracea), Stock (Matthiola Ait. f.)c, Strawberry (Fragaria x ananassa), Sunflower (Helianthus annuus), Tomato (Solanum lycopersicum), Tulip tree (Liriodendron tulipifera), Udo (Aralia cordata), Watermelon (Citrullus lanatus)

V. isaacii Inderb. et al. $\quad$ Artichoke (Cynara scolymus), Bear's breech (Acanthus mollis subsp. mollis), Brassica sp., Florist's daisy (Chrysanthemum x morifolium), Hairy nightshade (Solanum physalifolium), Lettuce (Lactuca sativa), Potato (Solanum tuberosum), Soil, Spinach (Spinacia oleracea), Tomato (Solanum lycopersicum)

\begin{tabular}{|c|c|c|c|}
\hline V. klebahnii Inderb. et al. & Artichoke (Cynara scolymus), Lettuce (Lactuca sativa) & USA (CA, WA) & $2 / 1$ \\
\hline $\begin{array}{l}\text { V. longisporum } \\
\text { Karapapa, Bainbr. } \\
\text { \& Heale }\end{array}$ & $\begin{array}{l}\text { Birdrape (Brassica rapa var. rapa), Broccoli (Brassica oleracea var. botrytis), } \\
\text { Cabbage (Brassica oleracea), Cauliflower (Brassica oleracea var. botrytis), } \\
\text { Field mustard (Brassica rapa var. rapa), Horseradish (Armoracia rusticana), } \\
\text { Oilseed rape (Brassica napus sp. oleifera), Sugar beet (Beta vulgaris), Turnip } \\
\text { (Brassica campestris sp. pekinensis), Wild radish (Raphanus raphanistrum) }\end{array}$ & $\begin{array}{l}\text { Belgium, France, } \\
\text { Germany, Italy, Japan, } \\
\text { Netherlands, Russia, } \\
\text { Sweden, UK, USA (CA, IL) }\end{array}$ & $10 / 10$ \\
\hline $\begin{array}{l}\text { V. nonalfalfae Inderb. } \\
\text { et al. }\end{array}$ & $\begin{array}{l}\text { Alfalfa (Medicago sativa), Cotton (Gossypium hirsutum), Hop (Humulus } \\
\text { lupulus), Petunia (Petunia sp.), Potato (Solanum tuberosum), Soil, Spinach } \\
\text { (Spinacia oleracea), Tomato (Solanum lycopersicum), Tree of heaven } \\
\text { (Ailanthus altissima), Wild celery (Apium graveolens) }\end{array}$ & $\begin{array}{l}\text { Belgium, Canada, China, } \\
\text { Cuba, Japan, Middle Asia, } \\
\text { Netherlands, Slovenia, } \\
\text { UK, USA (IL, PA) }\end{array}$ & $9 / 10$ \\
\hline V. nubilum Pethybr. & Potato (Solanum tuberosum), Soil & UK & $1 / 1$ \\
\hline V. tricorpus I. Isaac & $\begin{array}{l}\text { Carnation (Dianthus caryophyllus), Larkspur (Delphinium sp.), Lettuce (Lactuca } \\
\text { sativa), Potato (Solanum tuberosum), Soil, Tomato (Solanum lycopersicum) }\end{array}$ & $\begin{array}{l}\text { Japan, Netherlands, New } \\
\text { Zealand, UK, USA (CA) }\end{array}$ & $5 / 5$ \\
\hline $\begin{array}{l}\text { V. zaregamsianum } \\
\text { Inderb. et al. }\end{array}$ & $\begin{array}{l}\text { Tomato (Solanum lycopersicum), Potato (Solanum tuberosum), Lettuce } \\
\text { (Lactuca sativa), Tenweeks stock (Matthiola incana) }\end{array}$ & Israel, Japan, Middle Asia & $4 / 3$ \\
\hline
\end{tabular}

a ITS records were grouped into phylogenetic species in Figure 3 and by Inderbitzin et al. $(41,43)$ for the records not included in Figure 3 . Inderbitzin et al. $(41,43)$ provides hosts within each country.

b Host and geographic information of the eight GenBank records labeled $V$. longisporum associated with the $V$. dahliae clade in Figure 3 were not considered.

c Eight of ten Brassicaceae hosts (except Chinese cabbage and radish) of the $V$. dahliae clade not considering $V$. longisporum lineage A1/D3, were confirmed to be $V$. dahliae hosts with additional data as follows. Multigene DNA sequencing (42): horseradish, e.g., for $V$. dahliae strain PD727; cabbage, e.g., for V. dahliae strain PD584; oilseed rape, e.g., for V. dahliae strain PD717; stock, for V. dahliae strain PD680. V. dahliaelike conidial DNA content (14): broccoli, for $V$. dahliae strain Vd128. Formation of nit mutants (61) which are not inducible in $V$. longisporum (8): Brassica oleracea var. capitata, for V. dahliae strain VP63 $(=414-1)$ which is VCG4B; B. oleracea var. italica, for V. dahliae strain VP19 (=449-2) which is VCG2B; Lenspod whitetop, $V$. dahliae for strain VP66 (=467-2) which is VCG4B.

d Host and geographic information from records of $V$. longisporum lineage A1/D3 clustering in the $V$. dahliae clade were also included. 
GenBank sequences may become less of a problem in the future, as the number of official barcode sequences (38) is expected to increase.

To facilitate identification of Verticillium species, a website, VertShield (S. Kang, B. Park, P. Inderbitzin, and K. V. Subbarao, unpublished data) is being developed. The website comprises a curated set of DNA sequences of strains representing type specimens and other correctly identified sequences and can be queried using blast. However, positive identification is dependent on a $100 \%$ match between query and database sequence. If a query sequence does not have a match in the database, phylogenetic analyses using multiple loci are still required to conclusively determine whether the query sequence is derived from a new or an existing species.

We suggest that identification of Verticillium species and $V$. longisporum lineages involve at least the following steps, which are summarized in Figure 6: morphological identification with the help of a dichotomous key (41), molecular identification using a diagnostic PCR assay $(44,82)$, and a blast search against a reference set of ITS sequences, for instance at the VertShield website (S. Kang, B. Park, P. Inderbitzin, and K. V. Subbarao, unpublished data). Results should be reported and the rationale for selection of a name briefly discussed. Also, ITS sequences have to be submitted to GenBank, which ensures that phylogenetic analyses can be performed later if needed, and DNA extracts should be deposited in a public repository to permit additional DNA sequencing in the future.

\section{ORIGINS OF INFORMATION CONFUSION IN VERTICILLIUM AND CONSEQUENCES FOR VERTICILLIUM WILT MANAGEMENT}

Species names are carriers of information and are essential to the communication, storage, and retrieval of information (39). This system is critically important to biology including plant pathology $(31,70)$, but is dependent on a stable taxonomic framework to prevent the confusion of information between species.

Verticillium has had a long history of taxonomic instability and information confusion. This included the controversy about the status of $V$. dahliae as an independent species from $V$. albo-atrum, which has affected disease management. For instance in Australia, V. albo-atrum was once considered a widespread and important pathogen on many different hosts, which turned out to be incorrect (89). Many of the herbarium specimens and cultures associated with literature records were found to belong to $V$. dahliae instead, and V. albo-atrum could only be confirmed from potato in three southern states. Most importantly, none of the records of $V$. albo-atrum from alfalfa (lucerne) or hops could be confirmed, which is significant because $V$. albo-atrum is more virulent on these hosts than $V$. dahliae. As a consequence, the status of $V$. albo-atrum was updated to a pathogen of major quarantine significance for Australia, and new control measures to exclude it were proposed (89). The measures appear to have been successful, as there are currently no alfalfa or hops strains from Australia in GenBank (Table 1). Another source of information confusion

\section{V. albo-atrum $23 \%(9 / 40)$}

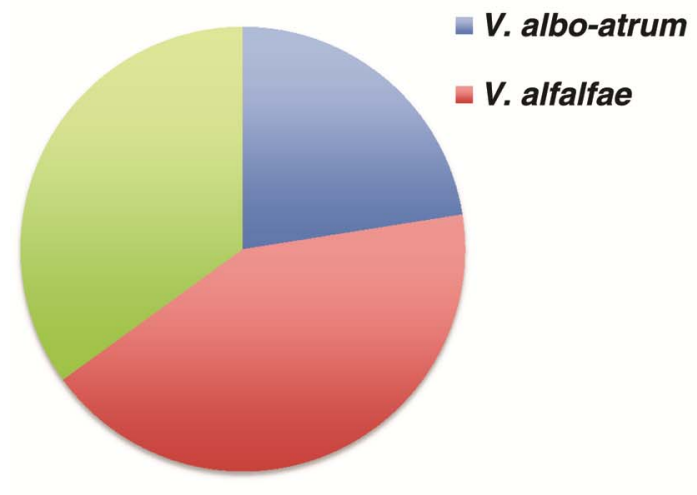

V. longisporum $78 \%(32 / 41)$

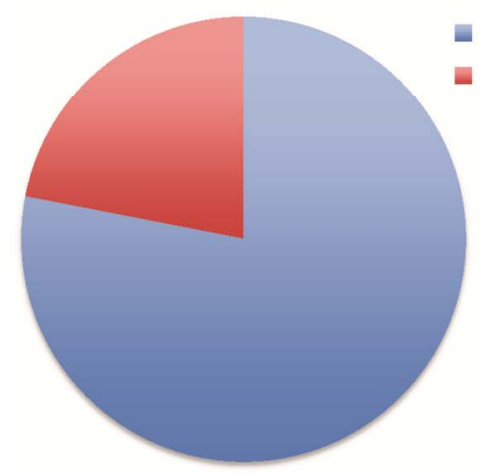

\section{V. dahliae $95 \%(433 / 455)$}

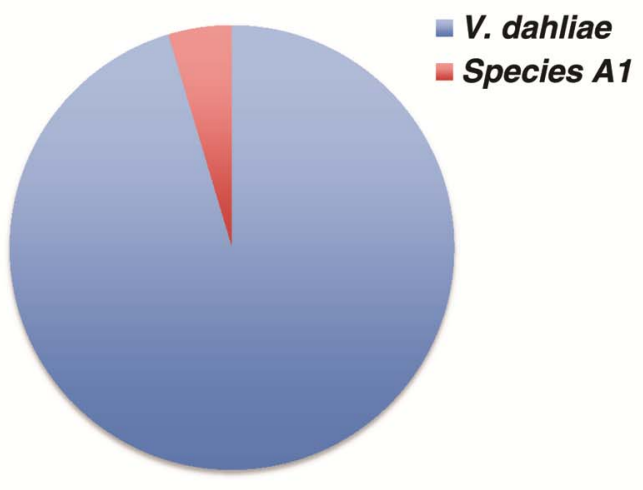

V. tricorpus $19 \%(5 / 26)$

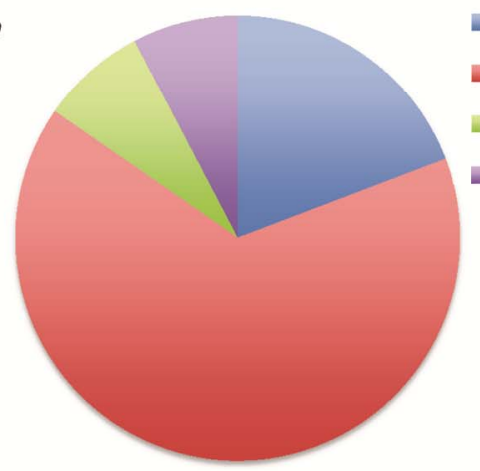

V. tricorpus

v. isaacii

V. klebahnii

V. zaregamsianum

\section{FIGURE 5}

Pie charts illustrating the proportions of correctly identified internal transcribed spacer (ITS) sequences in GenBank for select Verticillium species. Percentages of correctly identified sequences are given following each species name, preceding the numbers of correctly identified sequences and total number of sequences, which are in parentheses. Results were obtained by comparing species names on GenBank records with names inferred from phylogenetic analyses shown in Figure 3, and records in Inderbitzin et al. $(41,43)$ were not considered. 
in Verticillium are cryptic species that have only recently been formally named. These include $V$. alfalfae and $V$. nonalfalfae that were described for a lineage formerly in V. albo-atrum (41). This means that any record of $V$. albo-atrum may instead refer to $V$. alfalfae or $V$. nonalfalfae. Verticillium albo-atrum is morphologically very similar to $V$. alfalfae and $V$. nonalfalfae, and $V$. alfalfae and $V$. nonalfalfae are morphologically indistinguishable, so that reexamination of herbarium specimens cannot be used for reassessment of previous species identifications. Only DNA sequence data are reliable, but are unavailable for most of the $V$. albo-atrum literature. Thus, despite an over 130-year history as a plant pathogen, very little is known about the basic biology of $V$. albo-atrum, including host range and distribution, which certainly reduces the effectiveness of $V$. albo-atrum disease management. The problems are similar for $V$. tricorpus and the related cryptic species $V$. isaacii and V. klebahnii (41) but the three species are only minor pathogens. The practical importance of intraspecific diversity for disease management is illustrated by the bacterial citrus canker disease, where a newly discovered but less virulent pathovar triggered an unnecessary eradication effort to the cost of $\$ 93$ million $(23,76)$.

\section{STRAIN NAMES CANNOT BE CHECKED AND VERIFIED WITHOUT ADDITIONAL DATA}

Information confusion between species is a serious problem in Verticillium and has diminished the usefulness and relevance of much biological data accumulated over the course of almost a century. Theoretically, information confusion can easily be pre- vented by reevaluation of species names and the names of other taxa in the light of later knowledge. Examination of specimens kept in herbaria can serve this purpose if diagnostic morphological characters are available, as for separation of V. albo-atrum from $V$. dahliae, but cryptic species including $V$. alfalfae and $V$. nonalfalfae can only be distinguished using DNA. Compared with specimens and cultures, DNA has other advantages. DNA sequence data is accessible for anyone at repositories including GenBank and can be incorporated into phylogenetic analyses. Extracted DNA is stable and can be stored at room temperature at minimal cost and space requirements $(2,9)$, is available for genome sequencing, and may one day be used to create living organisms, as was done in bacteria (29). Also, a new classification system based on DNA (40) will likely complement and then replace the current one in the future, and information linked to DNA in GenBank could then be automatically associated with taxonomic groupings. DNA samples are currently accepted for storage at the Centraalbureau voor Schimmelcultures (CBS), and by the members of the DNA Bank Network (28) that include the New York Botanical Garden (NYBG) (12).

Despite all the advantages in maximizing the value of biological information, DNA data for taxa name assessment are not available for all recent articles. For instance, of the 90 research publications in 2012 to 2013 that present new data on V. alboatrum, only 56 of $90(62 \%)$ articles link the strains used to DNA sequence data suitable for assessment of species identification, and an even lower 10 of 90 (11\%) articles, if only articles are considered that do not include the $V$. alfalfae strain Ms.102 genome sequence (52) (Fig. 7). DNA data also illustrate that
FIGURE 6

Steps involved in the identification of Verticillium species. Implementing all steps will result in correct identification in most cases, and will establish a link between published research, DNA sequence data in GenBank, and a DNA sample, which ensures that the identification can be reevaluated in the future. GenBank submissions should at least note the date and location of collection, the substrate, and a reference to literature where the strain was published. For additional details, see text.
FIGURE 7

Pie chart illustrating that $62 \%$ of the 90 research articles on V. albo-atrum published in 2012 to 2013 include DNA data that can be used for retroactive species identification, either based on genome data (51\%) by Klosterman et al. (52), or other suitable DNA data (11\%). Only articles presenting new results with strains named V. albo-atrum were considered.

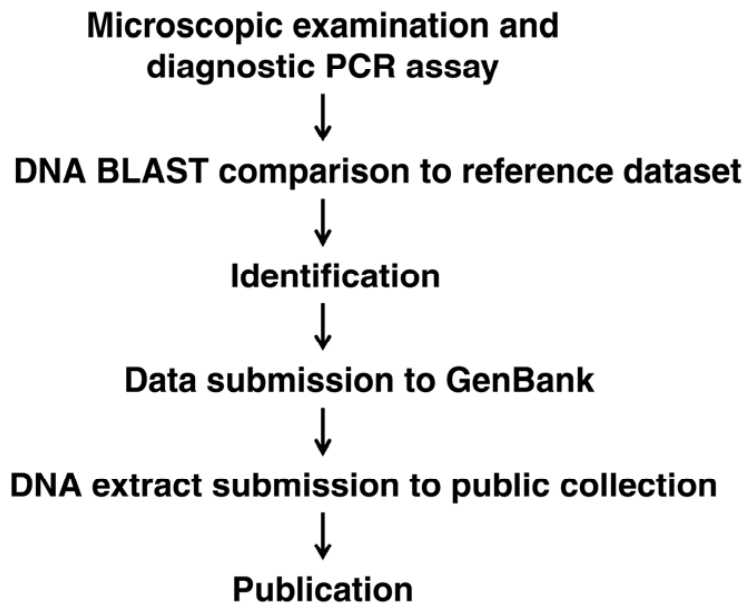

V. albo-atrum publications 2012-2013

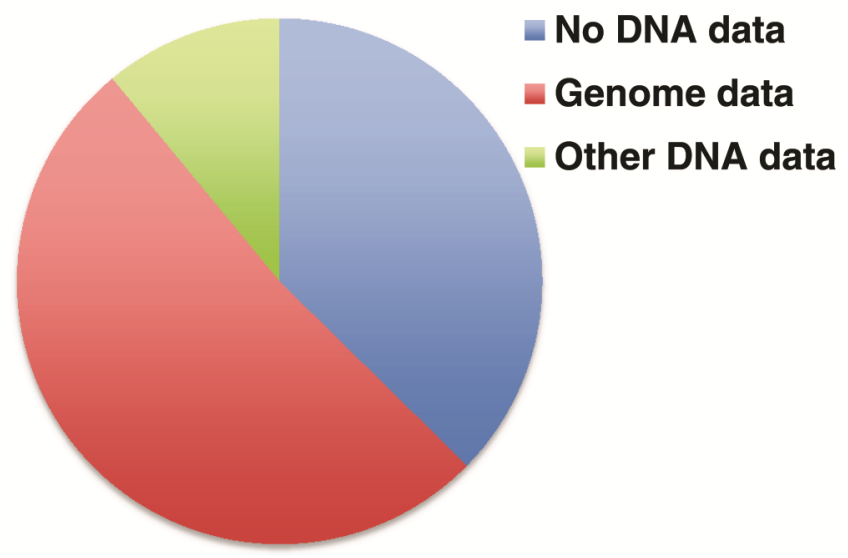


misidentification is an issue in V. albo-atrum, as of the 10 articles from the previous sentence where naming was verifiable, only two $(20 \%)$ used the name V. albo-atrum correctly (Supplemental data 6). Thus, V. albo-atrum is a good illustration for the need to release DNA sequences and DNA extracts for strains used in research, which increases the impact and relevance of the associated data in the long term and maximizes the return on time and funding invested in research.

\section{ADVANTAGES OF VERIFIABLE TAXON NAMES FOR DISEASE MANAGEMENT AND QUARANTINE REGULATIONS}

Taxon names that can be verified and assessed retroactively increase the quality of biological information about species and other taxonomic units and thereby have a direct impact on practical aspects of plant pathology. If biological information is properly categorized according to the taxa from which it was derived, including $V$. albo-atrum and $V$. dahliae in Australia as described above (89), or the $V$. dahliae olive defoliating and nondefoliating pathotypes in Spain (30), quarantine regulations are more effective in excluding pathogens and are less likely to drive up economic costs by unnecessarily rejecting or delaying goods during inspection. Also, an inaccurate knowledge base about differences and similarities between species and other taxa may delay the realization of improvements to the currently used disease management strategies.

\section{RECOMMENDATION}

Because species names are an imperfect means to archive and retrieve information in mycology and plant pathology, we propose that releasing DNA sequence data and DNA extracts into the public domain for all strains used in research should be a prerequisite for publication of all manuscripts. This system provides the means for an independent assessment of taxon names in case of information confusion, resulting in improved disease management strategies, and also has the added benefit of preserving genetic resources. We believe that a major effort is warranted to establish a national DNA repository system dedicated to plant pathology, which would be much cheaper and logistically less challenging than a culture collection but would provide many of the same benefits.

\section{ACKNOWLEDGMENTS}

We thank the following individuals for providing information about Verticillium isolates: W. Gams, formerly of CBS, Utrecht, Netherlands; B. Hudelson and G. Stanosz, University of Wisconsin, Madison; E. Ligoxigakis, Hellenic Agricultural Organization, Heraklion, Greece; and M. Typas, University of Athens, Athens, Greece. Many thanks to the following researchers for providing information about DNA repositories: L. Castlebury and A. Rossman, USDA-ARS, Beltsville; P. Crous, CBS, Utrecht, Netherlands; A. Lévesque, S. Redhead, and K. Seifert, Agriculture and Agri-Food Canada, Ottawa; and K. McCluskey, University of Missouri, Kansas City. We are indebted to R. Jiménez-Díaz, University of Cordoba and Institute of Sustainable Agriculture, Council for Scientific Research (CSIC), Cordoba, Spain, for commenting on $V$. dahliae from olive, and to C. Schoch, NCBI, National Institutes of Health, Bethesda, for providing information about DNA barcoding.

\section{LITERATURE CITED}

1. Altschul, S. F., Madden, T. L., Schäffer, A. A., Zhang, J., Zhang, Z., Miller, W., and Lipman, D. J. 1997. Gapped BLAST and PSI-BLAST: A new generation of protein database search programs. Nucleic Acids Res. 25:3389-3402.

2. Anchordoquy, T. J., and Molina, M. C. 2007. Preservation of DNA. Cell Preserv. Technol. 5:180-188.
3. Anonymous. 2010. The Plant List Version 1. Published on the Internet at http://www.theplantlist.org/

4. Atallah, Z. K., Hayes, R. J., and Subbarao, K. V. 2011. Fifteen years of Verticillium wilt of lettuce in America's salad bowl: A tale of immigration, subjugation, and abatement. Plant Dis. 95:784-792.

5. Babadoost, M., Chen, W., Bratsch, A. D., and Eastman, C. E. 2004. Verticillium longisporum and Fusarium solani: Two new species in the complex of internal discoloration of horseradish roots. Plant Pathol. 53:669-676.

6. Barbara, D. J., and Clewes, E. 2003. Plant pathogenic Verticillium species: How many of them are there? Mol. Plant Pathol. 4:297-305.

7. Berkeley, G. H., Madden, G. O., and Willison, R. S. 1931. Verticillium wilts in Ontario. Sci. Agric. 11:739-759.

8. Bhat, R., and Subbarao, K. V. 1999. Host range specificity in Verticillium dahliae. Phytopathology 89:1218-1225.

9. Bonnet, J., Colotte, M., Coudy, D., Couallier, V., Portier, J., Morin, B., and Tuffet, S. 2010. Chain and conformation stability of solid-state DNA: Implications for room temperature storage. Nucleic Acids Res. 38:15311546.

10. Brasier, C. M. 2001. Rapid evolution of introduced plant pathogens via interspecific hybridization. Bioscience 51:123-133.

11. Brochmann, C., Borgen, L., and Stabbetorp, O. 2000. Multiple diploid hybrid speciation of the Canary Island endemic Argyranthemum sundingii (Asteraceae). Plant Syst. Evol. 220:77-92.

12. Campbell, L., Quenzer, M., Dröge, G., Kirchgessner, A., Simpson, J., and Tulig, M. 2012. Tissue and DNA banking at The New York Botanical Garden. Collection Forum 26:120-129.

13. Cannon, P. F., Buddie, A. G., Bridge, P. D., de Neergaard, E., Lübeck, M., and Askar, M. M. 2012. Lectera, a new genus of the Plectosphaerellaceae for the legume pathogen Volutella colletotrichoides. MycoKeys 3:23-36.

14. Collins, A., Mercado-Blanco, J., Jiménez-Díaz, R. M., Olivares, C., Clewes, E., and Barbara, D. J. 2005. Correlation of molecular markers and biological properties in Verticillium dahliae and the possible origins of some isolates. Plant Pathol. 54:549-557.

15. Collins, A., Okoli, C. A., Morton, A., Parry, D., Edwards, S. G., and Barbara, D. J. 2003. Isolates of Verticillium dahliae pathogenic to crucifers are of at least three distinct molecular types. Phytopathology 93:364-376.

16. Collins, R. A., and Cruickshank, R. H. 2013. The seven deadly sins of DNA barcoding. Mol. Ecol. Resour. 13:969-975.

17. Correll, J. C., Gordon, T. R., and McCain, A. H. 1988. Vegetative compatibility and pathogenicity of Verticillium albo-atrum. Phytopathology 78:1017-1021.

18. Down, G., Barbara, D., and Radišek, S. 2007. Verticillium albo-atrum and V. dahliae on hop. EPPO Bull. 37:528-535.

19. Dunker, S., Keunecke, H., Steinbach, P., and von Tiedemann, A. 2008. Impact of Verticillium longisporum on yield and morphology of winter oilseed rape (Brassica napus) in relation to systemic spread in the plant. J. Phytopathol. 156:698-707.

20. Enebak, S. A. 2012. Soil fumigation: The critical use exemption, quarantine pre-shipment rules, re-registration decision and their effect on the 2012 growing season. Pages 26-30 in: National Proceedings: Forest and Conservation Nursery Associations-2011. D. L. Haase, J. R. Pinto, and L. E. Riley, eds. USDA Forest Service, Rocky Mountain Research Station, Fort Collins, CO.

21. Fradin, E. F., and Thomma, B. P. H. J. 2006. Physiology and molecular aspects of Verticillium wilt diseases caused by $V$. dahliae and V. alboatrum. Mol. Plant Pathol. 7:71-86.

22. Friebertshauser, G. E., and DeVay, J. E. 1982. Differential effects of the defoliating and nondefoliating pathotypes of Verticillium dahliae upon the growth and development of Gossypium hirsutum. Phytopathology 72:872877.

23. Gabriel, D. W., Kingsley, M. T., Hunter, J. E., and Gottwald, T. 1989. Reinstatement of Xanthomonas citri (ex Hasse) and Xanthomonas phaseoli (ex Smith) to species and reclassification of all Xanthomonas campestris pv. citri strains. Int. J. Syst. Bacteriol. 39:14-22.

24. Gams, W. 1971. Cephalosporium-artige Schimmelpilze (Hyphomycetes). G. Fischer, Stuttgart.

25. Gams, W., and Van Zaayen, A. 1982. Contribution to the taxonomy and pathogenicity of fungicolous Verticillium species. I. Taxonomy. Neth. J. Plant Pathol. 88:57-78.

26. Gams, W., and Zare, R. 2001. A revision of Verticillium sect. Prostrata. III. Generic classification. Nova Hedwigia 72:329-337.

27. Gams, W., Zare, R., and Summerbell, R. C. 2005. Proposal to conserve the generic name Verticillium (anamorphic Ascomycetes) with a conserved type. Taxon 54:179.

28. Gemeinholzer, B., Droege, G., Zetzsche, H., Knebelsberger, T., Raupach, M., Borsch, T., Klenk, H.-P., Haszprunar, G., and Waegele, J.-W. 2013. DNA Bank Network Webportal. Published online. http://www.dnabanknetwork.org 
29. Gibson, D. G., Glass, J. I., Lartigue, C., Noskov, V. N., Chuang, R.-Y., Algire, M. A., Benders, G. A., Montague, M. G., Ma, L., Moodie, M. M., Merryman, C., Vashee, S., Krishnakumar, R., Assad-Garcia, N., AndrewsPfannkoch, C., Denisova, E. A., Young, L., Qi, Z.-Q., Segall-Shapiro, T. H., Calvey, C. H., Parmar, P. P., Hutchison, C. A., Smith, H. O., and Venter, J. C. 2010. Creation of a bacterial cell controlled by a chemically synthesized genome. Science 329:52-56.

30. Gramaje, D., Pérez-Serrano, V., Montes-Borrego, M., Navas-Cortés, J. A., Jiménez-Díaz, R. M., and Landa, B. B. 2013. A Comparison of real-time PCR protocols for the quantitative monitoring of asymptomatic olive infections by Verticillium dahliae pathotypes. Phytopathology 103:10581068.

31. Harrington, T. C., and Rizzo, D. M. 1999. Defining species in the fungi. Pages 43-71 in: Structure and Dynamics of Fungal Populations. J. J. Worrall, ed. Kluwer Press, Dordrecht, The Netherlands.

32. Hawksworth, D. L. 1970. Verticillium nubilum. C.M.I. Descriptions of Pathogenic Fungi and Bacteria 26. Commonwealth Mycological Institute, Kew, Surrey, England.

33. Hawksworth, D. L. 1970. Verticillium nigrescens. C.M.I. Descriptions of Pathogenic Fungi and Bacteria 26. Commonwealth Mycological Institute, Kew, Surrey, England.

34. Hawksworth, D. L. 1970. Verticillium tricorpus. C.M.I. Descriptions of Pathogenic Fungi and Bacteria 26. Commonwealth Mycological Institute, Kew, Surrey, England.

35. Hawksworth, D. L., and Talboys, P. W. 1970. Verticillium albo-atrum. C.M.I. Descriptions of Pathogenic Fungi and Bacteria 26. Commonwealth Mycological Institute, Kew, Surrey, England.

36. Hawksworth, D. L., and Talboys, P. W. 1970. Verticillium dahliae. C.M.I. Descriptions of Pathogenic Fungi and Bacteria 26. Commonwealth Mycological Institute, Kew, Surrey, England.

37. Heale, J. B., and Isaac, I. 1963. Wilt of lucerne caused by species of Verticillium. IV. Pathogenicity of V. albo-atrum and V. dahliae to lucerne and other crops; spread and survival of V. albo-atrum in soil and weeds; Effect upon lucerne production. Ann. Appl. Biol. 52:439-451.

38. Hebert, P. D. N., and Gregory, T. R. 2005. The promise of DNA barcoding for taxonomy. Syst. Biol. 54:852-859.

39. Hey, J. 2009. Why should we care about species? Nature Education 2:2. http://www.nature.com/scitable/topicpage/why-should-we-care-about-species4277923

40. Hibbett, D. S., and Taylor, J. W. 2013. Fungal systematics: Is a new age of enlightenment at hand? Nat. Rev. Microbiol. 11:129-133.

41. Inderbitzin, P., Bostock, R. M., Davis, R. M., Usami, T., Platt, H. W., and Subbarao, K. V. 2011. Phylogenetics and taxonomy of the fungal vascular wilt pathogen Verticillium, with the descriptions of five new species. PLOS ONE 6:e28341.

42. Inderbitzin, P., Bostock, R. M., and Subbarao, K. V. 2012. Cylindrocladiella hahajimaensis, a new species of Cylindrocladiella transferred from Verticillium. MycoKeys 4:1-8.

43. Inderbitzin, P., Davis, R. M., Bostock, R. M., and Subbarao, K. V. 2011. The ascomycete Verticillium longisporum is a hybrid and a plant pathogen with an expanded host range. PLoS ONE 6:e18260.

44. Inderbitzin, P., Davis, R. M., Bostock, R. M., and Subbarao, K. V. 2013. Identification and differentiation of Verticillium species and $V$. longisporum lineages by simplex and multiplex PCR assays. PLoS ONE 8:e65990.

45. Isaac, I. 1949. A comparative study of pathogenic isolates of Verticillium. Trans. Br. Mycol. Soc. 32:137-157.

46. Isaac, I. 1953. A further comparative study of pathogenic isolates of Verticillium: V. nubilum Pethybr. and V. tricorpus sp. nov. Trans. Br. Mycol. Soc. 36:180-195.

47. Isaac, I. 1967. Speciation in Verticillium. Annu. Rev. Phytopathol. 5:201222.

48. Isaac, I., and Harrison, J. A. C. 1968. The symptoms and causal agents of early-dying disease (Verticillium wilt) of potatoes. Ann. Appl. Biol. 61:231-244.

49. Jimenez-Diaz, R. M., Cirulli, M., Bubici, G., del Mar Jimenez-Gasco, M., Antoniou, P. P., and Tjamos, E. C. 2012. Verticillium wilt, a major threat to olive production: Current status and future prospects for its management. Plant Dis. 96:304-329.

50. Karapapa, V. K., Bainbridge, B. W., and Heale, J. B. 1997. Morphological and molecular characterization of Verticillium longisporum comb. nov., pathogenic to oilseed rape. Mycol. Res. 101:1281-1294.

51. Klebahn, H. 1913. Beiträge zur Kenntnis der Fungi imperfecti. 1. Eine Verticillium-Krankheit auf Dahlien. Mycologisches Centralblatt 3:49-66.

52. Klosterman, S. J., Subbarao, K. V., Kang, S., Veronese, P., Gold, S. E., Thomma, B. P. H. J., Chen, Z., Henrissat, B., Lee, Y.-H., Park, J., GarciaPedrajas, M. D., Barbara, D. J., Anchieta, A., de Jonge, R., Santhanam, P., Maruthachalam, K., Atallah, Z., Amyotte, S. G., Paz, Z., Inderbitzin, P., Hayes, R. J., Heiman, D. I., Young, S., Zeng, Q., Engels, R., Galagan, J.,
Cuomo, C. A., Dobinson, K. F., and Ma, L.-J. 2011. Comparative genomics yields insights into niche adaptation of plant vascular wilt pathogens. PLoS Pathol. 7:e1002137.

53. Kvist, S. 2013. Barcoding in the dark: A critical view of the sufficiency of zoological DNA barcoding databases and a plea for broader integration of taxonomic knowledge. Mol. Phylogen. Evol. 69:39-45.

54. Latunde-Dada, A. O. 2001. Colletotrichum: Tales of forcible entry, stealth, transient confinement and breakout. Mol. Plant Pathol. 2:187-198.

55. Ludbrook, W. V. 1933. Pathogenicity and environal studies on Verticillium hadromycosis. Phytopathology 23:117-154.

56. Malcolm, G. M., Kuldau, G. A., Gugino, B. K., and Jiménez-Gasco, M. M. 2013. Hidden host plant associations of soilborne fungal pathogens: An ecological perspective. Phytopathology 103:538-544.

57. McNeill, J., Barrie, F. R., Buck, W. R., Demoulin, V., Greuter, W., Hawksworth, D. L., Herendeen, P. S., Knapp, S., Marhold, K., Prado, J., Prud'homme Van Reine, W. F., Smith, G. F., Wiersema, J. H., and Turland, N. J. 2012. International code of nomenclature for algae, fungi and plants (Melbourne code) adopted by the Eighteenth International Botanical Congress Melbourne, Australia, Vol. 154, Regnum vegetabile. Koeltz Scientific Books, Königstein, Germany.

58. Morton, A., Carder, J. H., and Barbara, D. J. 1995. Sequences of the internal transcribed spacers of the ribosomal RNA genes and relationships between isolates of Verticillium alboatrum and V. dahliae. Plant Pathol. 44:183-190.

59. Nees von Esenbeck, C. G. 1817. Das System der Pilze und Schwämme. Stahelsche Buchhandlung, Würzburg.

60. O'Donnell, K., Ward, T. J., Geiser, D. M., Kistler, H. C., and Aoki, T. 2004. Genealogical concordance between the mating type locus and seven other nuclear genes supports formal recognition of nine phylogenetically distinct species within the Fusarium graminearum clade. Fungal Genet. Biol. 41:600-623.

61. Papaioannou, I. A., Ligoxigakis, E. K., Vakalounakis, D. J., Markakis, E. A., and Typas, M. A. 2013. Phytopathogenic, morphological, genetic and molecular characterization of a Verticillium dahliae population from Crete, Greece. Eur. J. Plant Pathol. 136:577-596.

62. Pegg, G. F., and Brady, B. L. 2002. Verticillium Wilts. CABI Publishing, Wallingford, Oxon, UK.

63. Platt, H. W., MacLean, V., Mahuku, G., and Maxwell, P. 2000. Verticillium wilt of potatoes caused by three Verticillium species. Pages 59-62 in: Advances in Verticillium: Research and Disease Management. E. C. Tjamos, R. C. Rowe, J. B. Heale, and D. R. Fravel, eds. American Phytopathological Society, St. Paul, MN.

64. Qin, Q.-M., Vallad, G. E., and Subbarao, K. V. 2008. Characterization of Verticillium dahliae and V. tricorpus isolates from lettuce and artichoke. Plant Dis. 92:69-77.

65. Radišek, S., Jakše, J., and Javornik, B. 2006. Genetic variability and virulence among Verticillium albo-atrum isolates from hop. Eur. J. Plant Pathol. 116:301-314.

66. Ramos, B., González-Melendi, P., Sánchez-Vallet, A., SánchezRodríguez, C., López, G., and Molina, A. 2013. Functional genomics tools to decipher the pathogenicity mechanisms of the necrotrophic fungus Plectosphaerella cucumerina in Arabidopsis thaliana. Mol. Plant Pathol. 14:44-57.

67. Reinke, J., and Berthold, G. 1879. Die Kräuselkrankheit der Kartoffel. Untersuchungen aus dem Botanischen Laboratorium der Universität Göttingen 1:67-96.

68. Robb, J., Moukhamedov, R., Hu, X., Platt, H., and Nazar, R. N. 1993. Putative subgroups of Verticillium albo-atrum distinguishable by PCRbased assays. Physiol. Mol. Plant Pathol. 43:423-436.

69. Robinson, D. B., Larson, R. H., and Walker, J. C. 1957. Verticillium wilt of potato in relation to symptoms, epidemiology and variability of the pathogen. Wis. Agric. Exp. Stn. Bull. 202:1-49.

70. Rossman, A. Y., and Palm-Hernández, M. E. 2008. Systematics of plant pathogenic fungi: Why it matters. Plant Dis. 92:1376-1386.

71. Rowe, R. C., and Powelson, M. L. 2002. Potato early dying: Management challenges in a changing production environment. Plant Dis. 86:11841193.

72. Rudolph, B. A. 1931. Verticillium hadromycosis. Hilgardia 5:197-353.

73. Saccardo, P. A. 1886. Verticillium tenerum. Sylloge Fungorum 4:158.

74. Schall, M. J., and Davis, D. D. 2009. Ailanthus altissima wilt and mortality: Etiology. Plant Dis. 93:747-751.

75. Schoch, C. L., Seifert, K. A., Huhndorf, S., Robert, V., Spouge, J. L., Levesque, C. A., Chen, W., and Fungal Barcoding Consortium. 2012. Nuclear ribosomal internal transcribed spacer (ITS) region as a universal DNA barcode marker for fungi. Proc. Natl. Acad. Sci. USA 109:62416246.

76. Schubert, T. S., Rizvi, S. A., Sun, X. A., Gottwald, T. R., Graham, J. H., and Dixon, W. N. 2001. Meeting the challenge of eradicating citrus canker in Florida-again. Plant Dis. 85:340-356. 
77. Smith, H. C. 1965. The morphology of Verticillium albo-atrum, V. dahliae and V. tricorpus. N.Z. J. Agric. Res. 8:450-478.

78. Stark, C. 1961. Das Auftreten der Verticillium-Tracheomykosen in Hamburger Gartenbaukulturen. Gartenbauwissenschaft 26:493-528.

79. Stevens, P. F. 2001. Angiosperm Phylogeny Website. Version 12, July 2012. Published online. http://www.mobot.org/MOBOT/research/APweb/

80. Subbarao, K. V., Hubbard, J. C., Greathead, A. S., and Spencer, G. A. 1997. Verticillium wilt. Pages 26-27 in: Compendium of Lettuce Diseases. R. M. Davis, K. V. Subbarao, R. N. Raid, and E. A. Kurtz, eds. American Phytopathological Society, St. Paul, MN.

81. Taylor, J. W., Jacobson, D. J., Kroken, S., Kasuga, T., Geiser, D. M., Hibbett, D. S., and Fisher, M. C. 2000. Phylogenetic species recognition and species concepts in fungi. Fungal Genet. Biol. 31:21-32.

82. Tran, V., Braus-Stromeyer, S. A., Timpner, C., and Braus, G. H. 2013. Molecular diagnosis to discriminate pathogen and apathogen species of the hybrid Verticillium longisporum on the oilseed crop Brassica napus. Appl. Microbiol. Biotechnol. 97:4467-4483.

83. Usami, T., Kanto, T., Inderbitzin, P., Itoh, M., Kisaki, G., Ebihara, Y., Suda, W., Amemiya, Y., and Subbarao, K. V. 2011. Verticillium tricorpus causing lettuce wilt in Japan differs genetically from California lettuce isolates. J. Gen. Plant Pathol. 77:17-23.

84. USDA, NRCS. 2013. The PLANTS Database (http://plants.usda.gov/, 23 August 2013). National Plant Data Team, Greensboro, NC.

85. Vallad, G. E., Qin, Q.-M., Grube, R., Hayes, R. J., and Subbarao, K. V. 2006. Characterization of race-specific interactions among isolates of Verticillium dahliae pathogenic on lettuce. Phytopathology 96:1380-1387.

86. Van Beyma Thoe Kingma, F. H. 1939. Ueber einige Formen von Verticillium dahliae Kleb. Antonie van Leeuwenhoek J. Microbiol. Serol. 6:34-47.

87. Van den Ende, G. 1958. Untersuchungen über den Pflanzenparasiten Verticillium albo-atrum R. \& B. North-Holland Publishing Company, Amsterdam.

88. Van der Meer, J. H. H. 1925. Verticillium-wilt of herbaceous and woody plants. H. Veenman \& Zonen, Wageningen.

89. Walker, J. 1990. Verticillium albo-atrum in Australia: A case study of information confusion in plant pathology. Australas. Plant Pathol. 19:5769.

90. Wilhelm, S. 1955. Longevity of the Verticillium wilt fungus in the laboratory and field. Phytopathology 45:180-181.

91. Wilhelm, S., and Paulus, A. O. 1980. How soil fumigation benefits the California strawberry industry. Plant Dis. 64:264-270.

92. Wilhelm, S., and Taylor, J. B. 1965. Control of Verticillium wilt of olive through natural recovery and resistance. Phytopathology 55:310-316.

93. Wollenweber, H. W. 1929. Die Wirtelpilz-Welkekrankheit (Verticilliose) von Ulme, Ahorn und Linde usw. Arbeiten aus der Biologische Reichsanstalt für Land- und Forstwirtschaft 17:273-299.

94. Zare, R., and Gams, W. 2001. A revision of Verticillium section Prostrata. IV. The genera Lecanicillium and Simplicillium gen. nov. Nova Hedwigia 73:1-50.

95. Zare, R., and Gams, W. 2001. A revision of Verticillium section Prostrata. VI. The genus Haptocillium. Nova Hedwigia 73:271-292.

96. Zare, R., Gams, W., and Evans, H. C. 2001. A revision of Verticillium section Prostrata. V. The genus Pochonia, with notes on Rotiferophthora. Nova Hedwigia 73:51-86.

97. Zare, R., Gams, W., and Schroers, H.-J. 2004. The type species of Verticillium is not congeneric with the plant-pathogenic species placed in Verticillium and it is not the anamorph of 'Nectria' inventa. Mycol. Res. 108:576-582.

98. Zare, R., Gams, W., Starink-Willemse, M., and Summerbell, R. C. 2007. Gibellulopsis, a suitable genus for Verticillium nigrescens, and Musicillium, a new genus for $V$. theobromae. Nova Hedwigia 85:463-489.

99. Zhang, N., Castlebury, L. A., Miller, A. N., Huhndorf, S. M., Schoch, C. L., Seifert, K. A., Rossman, A. Y., Rogers, J. D., Kohlmeyer, J., Volkmann-Kohlmeyer, B., and Sung, G.-H. 2006. An overview of the systematics of the Sordariomycetes based on a four-gene phylogeny. Mycologia 98:1076-1087. 